\title{
Investigation of the distribution and Fe content of iron sand at Wari Ino beach Tobelo using resistivity method with werner-schlumberger configuration
}

\author{
Bayu Achil Sadjab $^{1 *}$, I Putu Tedy Indrayana ${ }^{2}$, Steven Iwamoni ${ }^{3}$, Rofiqul Umam ${ }^{4}$ \\ ${ }^{1,2}$ Physics Study Program, Faculty of Natural Science and Engineering Technology, Universitas Halmahera, Maluku \\ Utara, Indonesia. \\ ${ }^{3}$ Environmental Agency of Kabupaten Halmahera Utara, Maluku Utara, Indonesia \\ ${ }^{4}$ Faculty of Science and Technology, Kwansei Gakuin University, Hyogo, Japan \\ *Corresponding Address: bayu0604@gmail.com
}

\begin{abstract}
Article Info
Article history:

Received: December $7^{\text {th }}, 2019$

Accepted: April $24^{\text {th }}, 2020$

Published: April 30th 2020

\section{Keywords:}

Distribution;

Fe content;

Iron sand;

Resistivity;

Werner-Schlumberger

ABSTRACT

This research aimed to investigate the distribution, volume, and concentration of iron sand at Wari Ino Beach Tobelo. The resistivity method with Werner-Schlumberger configuration was applied to investigate the iron sand distribution. The measurements were set-up on 3 lines that run parallel along the coast of Wari Ino Village. The length of each trajectory was 150 meters with a spacing of 10 meters for each electrode. Data acquisition was carried out by using geoelectric instruments to obtain current injection (I) and voltage (V). The analysis was carried out by using RES2DINV and ROCKWORK software to obtain 2-D and 3-D cross-section models for interpreting the distribution and volume of the iron sand. The analysis and interpretation were supported by geological data of the location. Furthermore, the $\mathrm{Fe}$ content was characterized by using X-Ray Fluorescence Spectroscopy (XRF). There results show that the volume of the iron sand in each trajectory was $109,355 \mathrm{~m}^{3} ; 180,254 \mathrm{~m}^{3}$; and $120,556 \mathrm{~m}^{3}$. The total volume of iron sand along the three trajectories was up to $405,335 \mathrm{~m}^{3}$. The $\mathrm{Fe}$ content in the form of a free element is $67.41 \%, 57.12 \%$, and $73.40 \%$. The $\mathrm{Fe}$ content in the form of hematite mineral $\left(\mathrm{Fe}_{2} \mathrm{O}_{3}\right)$ was $57.92 \%$, $45.82 \%$, and $65.47 \%$.
\end{abstract}

(C) 2020 Physics Education Department, UIN Raden Intan Lampung, Indonesia.

\section{INTRODUCTION}

Iron sand contains abundant Fe element in the form of iron oxide minerals, i.e. magnetite $\left(\mathrm{Fe}_{3} \mathrm{O}_{4}\right)$, hematite $\left(\alpha-\mathrm{Fe}_{2} \mathrm{O}_{3}\right)$, and maghemite $\left(\gamma-\mathrm{Fe}_{2} \mathrm{O}_{3}\right)$. Other minerals such as Aluminum oxide $\left(\mathrm{Al}_{2} \mathrm{O}_{3}\right)$, Silica dioxide $\left(\mathrm{SiO}_{2}\right)$, Phosphorus pentaoxide $\left(\mathrm{P}_{2} \mathrm{O}_{5}\right)$, Calcium oxide $(\mathrm{CaO})$, Titanium dioxide $\left(\mathrm{TiO}_{2}\right)$, Vanadium pentaoxide $\left(\mathrm{V}_{2} \mathrm{O}_{5}\right)$, Chromium (III) oxide $\left(\mathrm{Cr}_{2} \mathrm{O}_{3}\right)$, and Manganese oxide $(\mathrm{MnO})$ also have been investigated exist in the iron sand(Malega et al., 2018). Generally, the primary minerals contained in the iron sand are Magnetite $\left(\mathrm{Fe}_{3} \mathrm{O}_{4}\right)$, Hematite $\left(\mathrm{Fe}_{2} \mathrm{O}_{3}\right)$, Goethite
$\left(\mathrm{Fe}_{2} \mathrm{O}_{3} \cdot \mathrm{H}_{2} \mathrm{O}\right)$, Siderite $\left(\mathrm{FeCO}_{3}\right)$ and Pyrite $\left(\mathrm{FeS}_{2}\right)$ (Lawan et al., 2018). Those minerals can be separated into a pure monophase mineral for the specific applications. Hence, they have high economic value and impact on the development of the mining industry in Indonesia.

The fabricated iron minerals in the form of iron metal and steel are very useful for many applications, such as fabrication of components for electronic devices, manufacturing, construction sector, building, vehicles industry as well as for the automotive sector. According to (The Indonesia Iron and Steel Industry 
Association, 2017), Indonesia has been experienced an increasing domestic steel consumption were 12.70 million tons in 2016 and projected to be $16.00 ; 17.00$; $18.00 ; 19.10 ; 20.20$; and 21.40 million tons in 2020 to 2045 in its year in ASEAN, Indonesia has the lowest steel consumption In 2020, Indonesia's steel consumption is predicted achieving of $84 \mathrm{~kg} / \mathrm{capita}$ that lower than ASEAN steel consumption about $157 \mathrm{~kg} /$ capita. This increase in steel consumption throughout its multiplier effect should be concerned by the government of Indonesia.

In a different case, the synthesized iron sand in the form of iron oxide into any kind of nano-materials also has a high economic impact. The synthesis of nanomaterials from iron sand is the basis for manufacturing new types of functional materials to support advance technologies, such as MRI contrast agent, drug delivery agent, biosensor optic, magnetic sensor, catalyst material, nanoadsorbent, antimicrobial, anticancer materials, as well as nano-imaging probe (Bolívar \& González, 2019; Dang et al., 2018; Rahimnia et al., 2019; Sardana et al., 2018).

Many researchers in Indonesia have developed nanomaterials based on local iron sand, for instance nanocomposite based iron oxide materials as an absorbent of the heavy metals (Azmiyawati et al., 2017; Rahmawati et al., 2017; Ramelan et al., 2016; Rettob, 2019; Sebayang et al., 2018; Setiadi et al., 2016; Putri et al., 2019). The $\mathrm{Fe}_{3} \mathrm{O}_{4}$ based nanocomposite material has fabricated for nuclear radiating shielding (Dahlan et al., 2018; Haryati \& Dahlan, 2018). The nanocomposite of $\mathrm{Fe}_{3} \mathrm{O}_{4} / \mathrm{PEG}-4000$ by (Arista et al., 2019) has aplicated for antibacterial material againts Escherichia Coli and Staphylococcus aureus. The $\mathrm{Fe}_{3} \mathrm{O}_{4}$ nanoparticles have also applied for ink powder (Fahlepy et al., 2018). Other researchers also synthesized nanomaterials based on iron sand for other various applications, for example magnetic thin film (Rianto et al., 2018; Yulfriska et al., 2018); electromagnetic wave absorbing material (Yusmaniar et al., 2018); heat transfer application (Imran et al., 2018); catalyst material (Maulinda et al., 2019); and magnetic nano-pigment (Yulianto et al., 2019).

Therefore, the exploration of the iron sand is very important for the development of the iron sand industry in Indonesia in the future. Indonesia has a lot of iron sand sites where they can be explored to be able supplying the iron sand raw material. The iron sand industry will be a future strategic and potential sector for Indonesia as the last detail explanation.

Many iron sand deposits belonged by Indonesia are distributed over all sites inits region, such as Buaya River Deli Serdang North Sumatra (Setiadi et al., 2016), Talang Mountain West Sumatra (Pratiwi et al., 2017), WediIreng Beach Banyuwangi East Java (Taufiq et al., 2017), Marina Beach, Semarang (Azmiyawati et al., 2017), Bugel Beach, Kulon Progo (Fahmiati et al., 2017), Betaf Beach, Sarmi Regency Jayapura (Dahlan et al., 2018; Haryati \& Dahlan, 2018), Cemara Sewu Beach Cilacap Central Java (Nurrohman \& Pribadi, 2018), Sampulungan Beach, Taklar Regency South Sulawesi (Arsyad et al., 2018), and Lampanah-Lengah village, District of Aceh Besar (Adlim et al., 2019).

In addition, Pusat Sumber Daya Geologi (PSGD) Ministry of Energy and Mineral Resources has reported in 2013 that there are 67 sites where the iron sand distributed in Indonesia (Suprapto \& Sunuhadi, 2014). There are many sites elsewhere the iron sand deposits not explored yet, for an instant a site at Wari Ino Beach, Tobelo Halmahera Utara. A pilot study by (Malega et al., 2018) had conducted only for identifying the minerals contained in iron sand at Wari Ino Beach by using X-Ray Fluorescence (XRF) Spectroscopy method. The research reported that the concentration of $\mathrm{Fe}$ mineral is about $87.5 \%$ of the iron sand mass.

Up to the date no publication provides information about the distribution and 
volume of the iron sand in Wari Ino Beach. Consequently, we investigated the distribution and volume of the iron sand in this site. By knowing the distribution, volume, and $\mathrm{Fe}$ content will allow further researchers to do exploration and also being a database for local government, especially the Department of Natural Resources, Mines and Energy, Maluku Utara for further iron sand industry strategic plan in Halmahera Utara.

The distribution and volume of the iron sand can be estimated by geophysical techniques, i.e., Magnetic techniques, Gravity techniques, Magnetotelluric technique, Induced-Polarization technique, and Electrical Resistivity techniques. The magnetic technique is the oldest geophysical techniques which measure deposit of the iron sand based on the variation in the susceptibility. Gravity techniques to measure density contrast between minerals and surrounding rocks. The magnetotelluric technique measures electrical conductivity of the iron sand. Those three techniques are classified into a passive technique based on signal propagation via investigated minerals or rocks (Adewuyi \& Ahmed, 2019). Hence, signal is not required to penetrate the iron sand deposit.

In other hands, Induced-Polarization technique measures the volume and the distribution of the iron sand based on the value of their capacitance. Electrical Resistivity technique measures electrical conductivity of iron sand. These two techniques are classified into active technique which signal directly penetrate the iron sand deposit (Adewuyi \& Ahmed, 2019). Among those techniques, Electrical Resistivity technique is the most applied for the investigation of the distribution and volume of iron sand deposit.

According to a research paper by (Sehah et al., 2018), the distribution and volume of the iron ore in Eastern Binangun Coastal Cilacap. Those data were interpreted base on the resistivity data obtained by using Werner configuration. Another paper by
(Raharjo \& Sehah, 2018) had reported the distribution of the iron sand in the western coastal area of Nusawungu, Cilacap Regency by applying the resistivity method with Schlumberger configuration. The results showed that the iron sand deposits are at depths of 2.39-25.25 meters with resistivity values of $12.24-46.96 \Omega \mathrm{m}$.

Werner configuration is only suitable for survey mapping of the iron sand distribution along the horizontal trajectory, but no more information about a sounding on the vertical direction. On the other hand, Schlumberger configuration is only suitable for identifying the vertical configuration of the iron sand (Raharjo \& Sehah, 2018; Sehah et al., 2018).

In this research, we applied the WernerSchlumberger configuration due to the configuration to find out the information both mapping and sounding of the iron sand volume and distribution under the surface instantaneously as explained by (Akmam et al., 2019; Jamaluddin \& Umar, 2018). We have been successfully obtained the 2-D cross-section contour of lower rock surface resistivity along the trajectories. In addition, we also obtained the Pseudo 3-D crosssectional area of iron sand in the trajectories. These results are potentially useful for further consideration in exploring iron sand at Wari Ino Beach.

\section{METHODS \\ Resistivity Method}

The geoelectric method can be used well if there is a resistivity contrast between mediums. Contrast can be a medium that is relatively conducive to a non-conductive medium, or there are lithological differences. Each type of rock subsurface has different resistivity values. Each resistivity depends on the density, moisture content, minerals, salt content, and rock porosity (Sehah et al., 2018). The work of the geoelectric method is by flowing direct current or alternating low frequency into the earth medium through two current electrodes, then measuring the potential 
difference arising through the two potential electrodes. (Naveen et al., 2015) explained that the distance between the electrodes can vary according to the area specification and the topography, so that the resistivity value can be calculated through Ohm's law. Suppose that $R$ is the resistance (Ohm); $A$ is the cross-sectional area of the medium $\left(\mathrm{m}^{2}\right)$, and $L$ is the length of the medium (m), then according to Figure 1, the resistivity of the medium, $\rho(\Omega \mathrm{m})$ can be determined by using equation 1 ,

$$
\rho=R \frac{A}{L}
$$

According to Ohm's law that the resistance $R$ of the medium mathematically can be calculated by using equation 2 , such as

$$
R=\frac{\Delta V}{I}
$$

Following the potential difference between edges of the medium $\Delta \mathrm{V}$ and the injected current I, so the resistivity can be calculated by equation 3 ,

$$
\rho=\frac{\Delta V}{I} \cdot \frac{A}{L}
$$

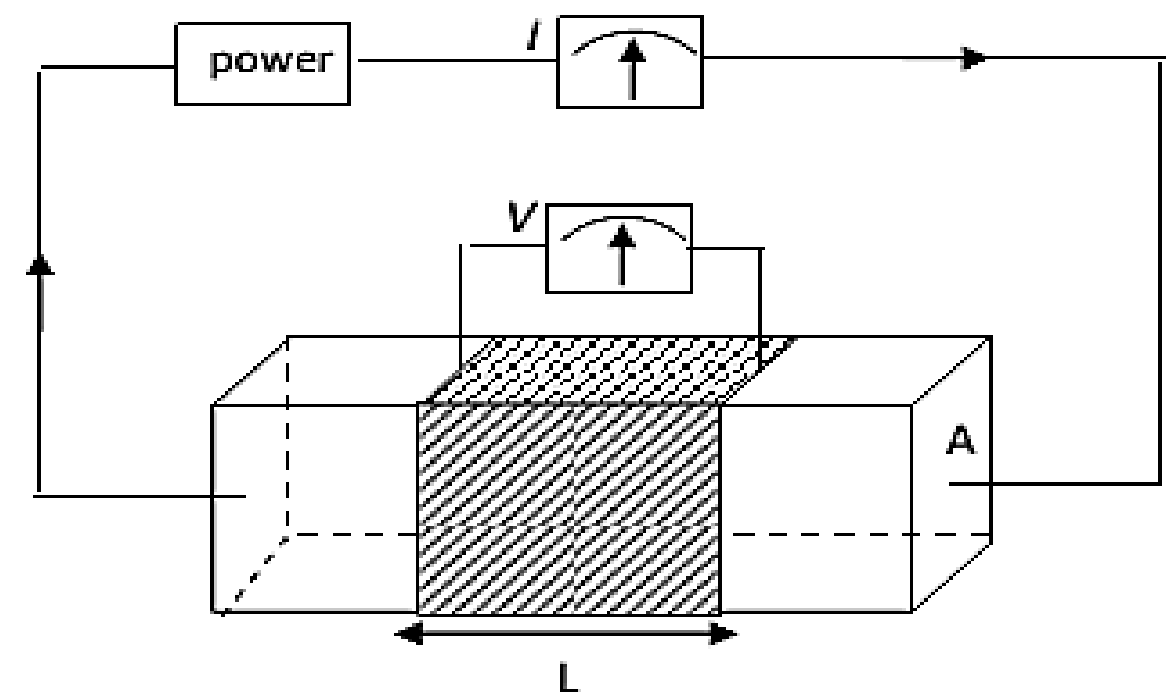

Figure 1. Samples of the medium through which current $I$, length $L$, and cross-sectional area $A$.

Equation 3 applies to a homogeneous medium, so the result obtained is true resistivity. But in practice, the object measured is the earth or soil that is not homogeneous because of different types of resistors, so that the measured resistivity is apparent resistivity. The apparent resistivity value depends on the resistivity of the layers forming the formation and the configuration of the electrodes used. Pseudo resistivity $\rho_{a}$ is formulated by equation 4 ,

$$
\rho_{a}=K \frac{\Delta V}{I}
$$

Where $K$ is the geometrical factor.

\section{Wenner-Schlumberger Configuration}

The Wenner-Schlumberger configuration is a configuration with a constant spacing system with a note that the comparison factor $\mathrm{n}$ for this configuration is the ratio of the distance between the current electrode $(\mathrm{AB})$ and the potential $(\mathrm{MN})$. If the potential electrode distance $\mathrm{MN}$ is a distance of the $\mathrm{AB}$ electrode is $(2 n a+a)$ (Figure 2).

This configuration is a combination of the Wenner configuration and the Schlumberger configuration. In measurements with a space factor $n=1$, the Wenner-Schlumberger configuration is the same as the measurement in the Wenner configuration (distance between electrodes $=$ a), but in measurements with $n=2$ and so on, the Wenner-Schlumberger configuration is the same as the Schlumberger configuration (the distance between current electrode and potential electrode are greater than the distance between potential electrodes). 
The Wenner-Schlumberger configuration has a penetration depth of up to one-third of the distance between $\mathrm{C} 1$ and $\mathrm{C} 2$. Commonly, the average penetration depth is up to 90 meters and Wenner configuration only reaches 80 meters. Variable $\mathrm{n}$ is multiple to show the observed layer's layers. The geometry factors of the WennerSchlumberger can be calculated by using equation 5 ,

$$
K=\pi(n+1) a
$$

where $a$ is the distance between the electrodes $\mathrm{P}_{1}$ and $\mathrm{P}_{2}, n$ is the ratio between the electrode distances $\mathrm{C}_{1}-\mathrm{P}_{1}$ and $\mathrm{P}_{1}-\mathrm{P}_{2}$ (e.g
$4 a$, then $n=4$ ) so that the resistivity value of all obtained from the measurement results is equal to equation 6 ,

$$
\rho_{a}=\pi(n+1) a \frac{\Delta V}{I}
$$

Generally, rock resistivity values have been obtained through various direct measurements and can be used as a reference in interpreting the results of field resistivity measurements; this is because certain resistivity values will be associated with geological conditions in the measurement area (Table 1).

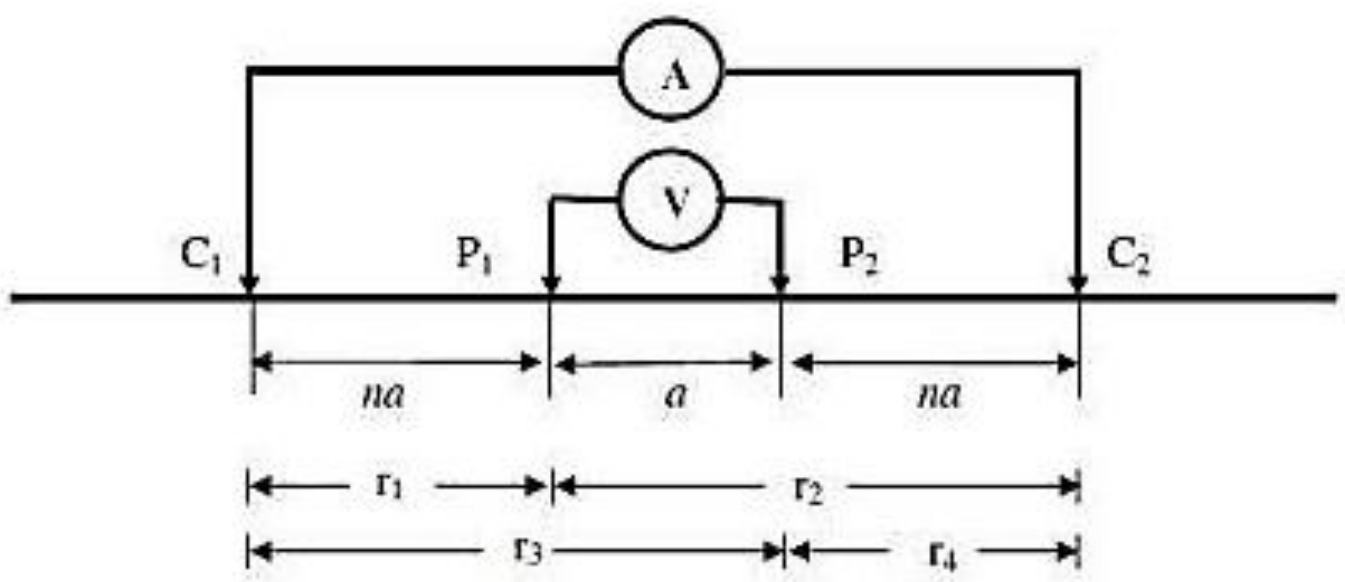

Figure 2. The Wenner-Schlumberger configuration

Table 1. Resistivity value of rock and minerals (Octova \& Yulhendra, 2017)

\begin{tabular}{l|r}
\hline \multicolumn{1}{c}{ Rock and Minerals } & Resistivity Range $(\mathbf{\Omega m})$ \\
\hline Rock & $50-100$ \\
\hline Top Soil & $100-2500000$ \\
Kuarsite & $1-100$ \\
clay & $200-8000$ \\
Sandstone & $500-10000$ \\
Limestones & $200-100000$ \\
Granite & \\
\hline Mineral & $0.001-100$ \\
\hline Galena & $0.001-0.01$ \\
Phyrotite & $0.001-10000$ \\
Hematite & $1000-1000000$ \\
Sphalerite & $0.01-1000$ \\
Magnetite & $0.001-10000$ \\
Cassiterite & $0.01-100$ \\
Pyrite &
\end{tabular}

According to (Sunarya et al., 2017), characteristics of iron sand deposits are generally stand-alone, but not infrequently also found in association with other rock minerals. The resistivity value of metal minerals can also be used as a reference in interpreting the results of measurements, where magnetic is a metal mineral with the 
highest Fe content, but the amount is small while hematite is the most needed iron mineral in the iron industry.

\section{Technical Procedures}

The research was conducted by direct observation and measurement in the field.
The research location is along the coast of Wari Ino Village, TobeloSubdistrict, North Halmahera Regency. Measurements were made on 3 lines that run parallel along the coast of Wari Ino Village, the length of each trajectory is 150 meters with a spacing of 10 meters for each electrode (Figure 3 ).

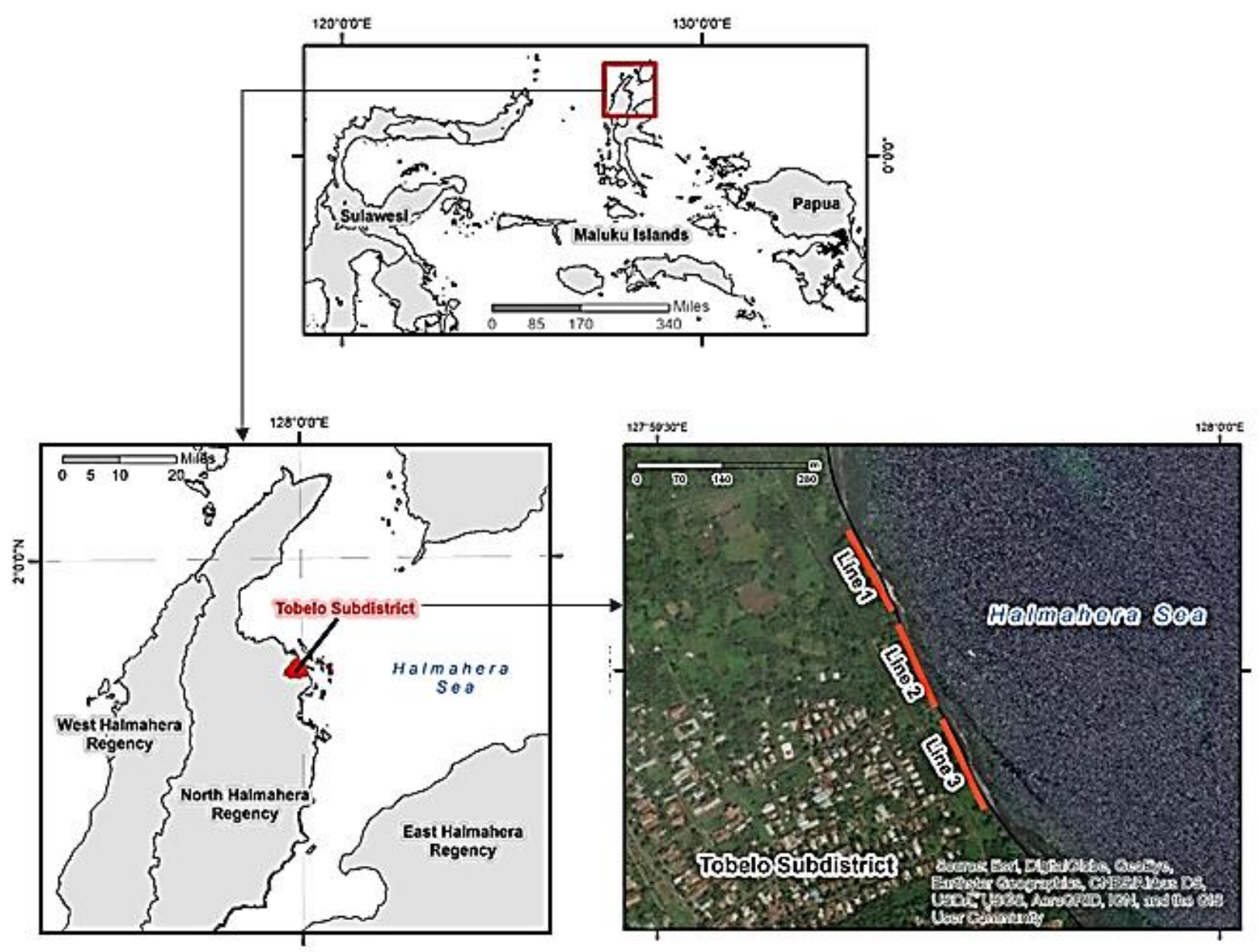

Figure 3. Map of the research location and the research survey design.

The research process was started from the preparation, study of literature, data acquisition, processing, analysis, and interpretation by software. Graphically, the research procedure can be displayed in Figure 4. The preparation phase includes preparation of tools and study materials, literature study includes a review of previous research that is geological data on location and $\mathrm{Fe}$ content data based on a microstructural synthesis of $\mathrm{Fe}_{3} \mathrm{O}_{4}$ in the iron sand of Wari Ino beach area, Tobelo sub-district Halmahera Utara, the acquisition of data includes the implementation of data collection activities in the field, in this case, uses a geoelectric tool to obtain current injection value $(I)$ and voltage value $(V)$, current and voltage injection value data is then processed to obtain resistivity values which are then reprocessed using RES2DINV software to obtain 2-D cross-section models (Jamaluddin \& Umar, 2018) and ROCKWORK software forget a 3-D crosssection model. This software works based on the inversion technique related to the last 
square method (Akmam et al., 2019; Pratiwi et al., 2019). The RES2DINV is an appropriate algorithm that considered good for 2D resistivity data inversion, and there is great scientific literature where the RMS of 2D electrical imaging is greater than $10 \%$ (Satriani et al., 2012). The results of the processing in the form of a cross-section are then analyzed and interpreted to determine the distribution and estimation of the volume of iron sand along the coast of Wari
Ino, Tobelo sub-district, North Halmahera district, this analysis and interpretation are supported by geological data of the location.

The $\mathrm{Fe}$ concentration in each iron sand sample is characterized by X-Ray Fluorescence Spectroscopy (XRF). The concentration of $\mathrm{Fe}$ in the form of $\mathrm{Fe}$ element and its compound can be identified by using this technique as reported by (Malega et al., 2018).

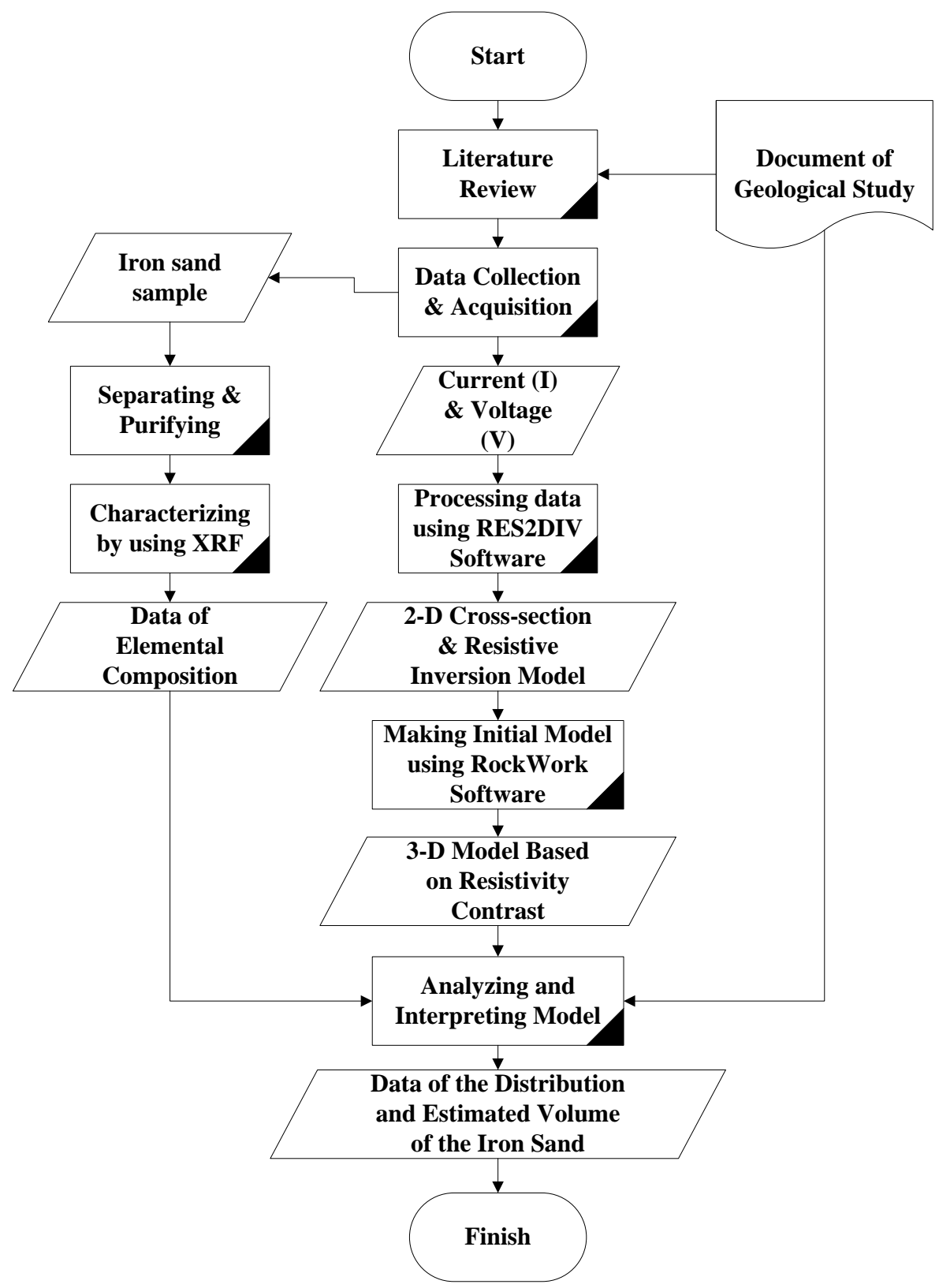

Figure 4. Schema of the research procedure. 


\section{RESULTS AND DISCUSSION Geology of Research Location}

The physiography of the research area is divided into 3 parts, West Halmahera Mandala, East Halmahera Mandala, and Quaternary Volcano (Chandra \& Hall,
2016). Rock dominance in the study area includes Alluvium, Tufa, Andesite, Sediment, Clays, Napal, Conglomerate, Ultramafic, Breccia, and Metamorphic Rocks (Figure 5).
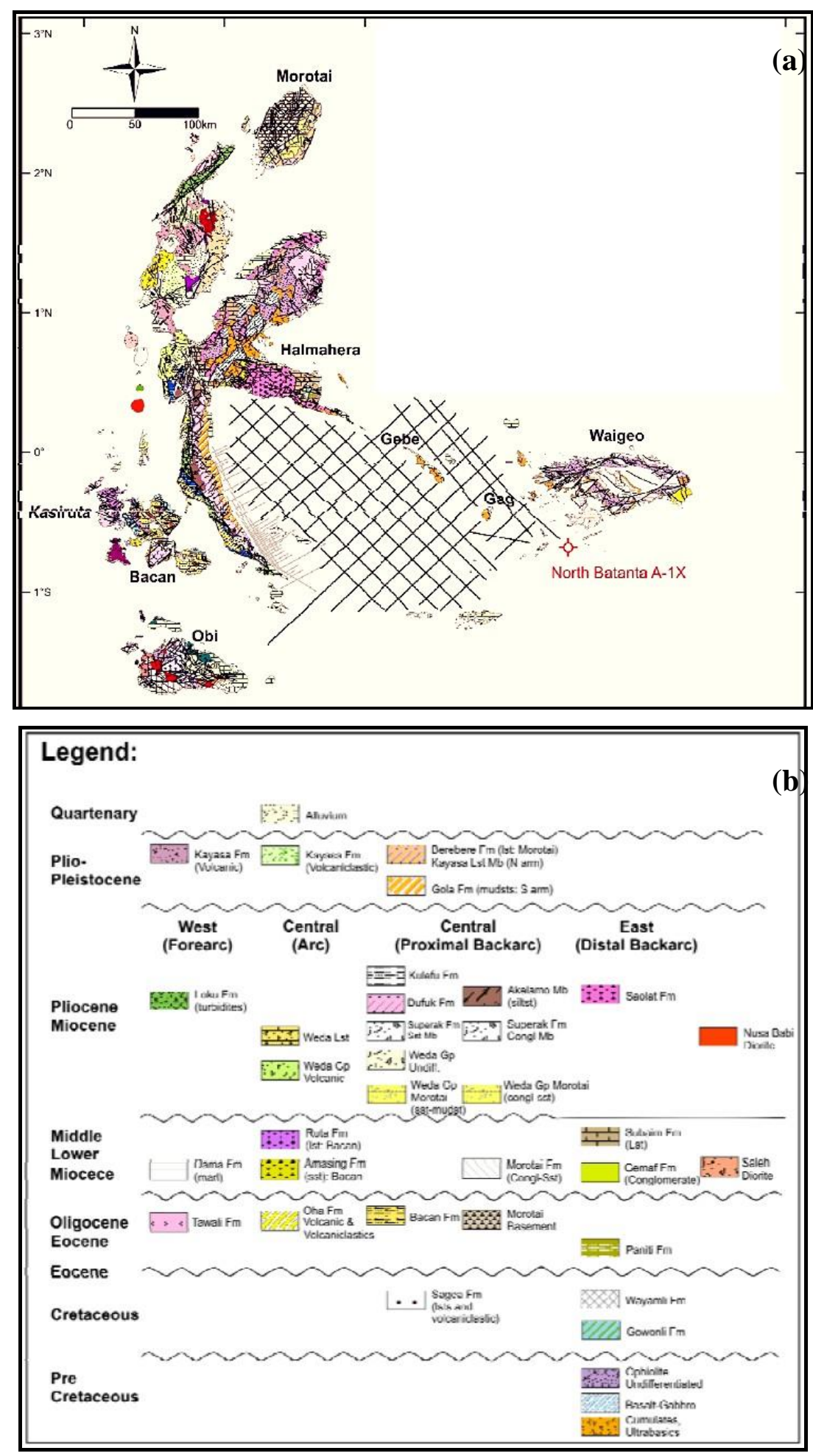

Figure 5. (a) Regional geological map of Halmahera Islandand (b) the legend (Chandra \& Hall, 2016) 
The stratigraphy of the study area consists of 17 formations composed of age ranges before the Cretaceous to the Holocene. The rock structure consists of Sedimentary Rocks with Dodaga Formation (Kd), Limestone Unit, Dogosagu Formation (Tped), Conglomerate Unit (Tpec), Tutuli Formation (Tomt), Conglomerate (Tmpc), Tingteng Formation (Tmpt), Vedic Formation (Tmpw), and Reef Limestone (Q1). Surface Deposition is with Alluvium and Coastal Deposition (Qa). GunungApi Rock with the composition of Bacan Formation (Tomb), Kayasa Formation (Qpk), Unit Tufa (Qht), MountApi Holocene Rock (Qhv). The igneous rocks are composed of Ultrabasic Rock (Ub), Gabro (Gb), and Diorite (Di) (Figure 5).

\section{The Distribution of Iron Sand}

Measurement data of observations were obtained a current (I), voltage $(\Delta \mathrm{V})$, apparent resistivity $(\rho)$, datum point data, spaces, number of layers. The processing by RES2DINV software for the three trajectories that run parallel along the coast of Wari Ino village. The results of 2-D inversion then saved into a format (.xyz). Data with the format (.xyz) consists of the accumulation of electrode distances, resistivity values, depth of current penetration, and subsurface conductivity based on measurement results.

Trajectory 1: inversion of resistivity data were presented in 2-D cross-section (Figure 6 ). Based on the color resistivity contrast of the surface, the blue to light green has a resistivity value $(\rho)$ smaller than $10 \Omega \mathrm{m}$, this layer interpreted as a layer of iron sand deposition at a depth of $2.5-25 \mathrm{~m}$ below the surface, forming spots deposits are scattered at a distance of $15-110 \mathrm{~m}$ with an average thickness of $10 \mathrm{~m}$. Also, variations in yellow and orange color with a range of resistivity values between $20 \Omega \mathrm{m}-50 \Omega \mathrm{m}$, the layer was at a depth of $7-12 \mathrm{~m}$ below the surface and the rock layer is interpreted as a clay rock. Then, the red to purple with a resistivity range between $55 \Omega \mathrm{m}-150 \Omega \mathrm{m}$ at a depth of 15-25 m below the surface was interpreted as a layer of breccia rocks scattered throughout the study area

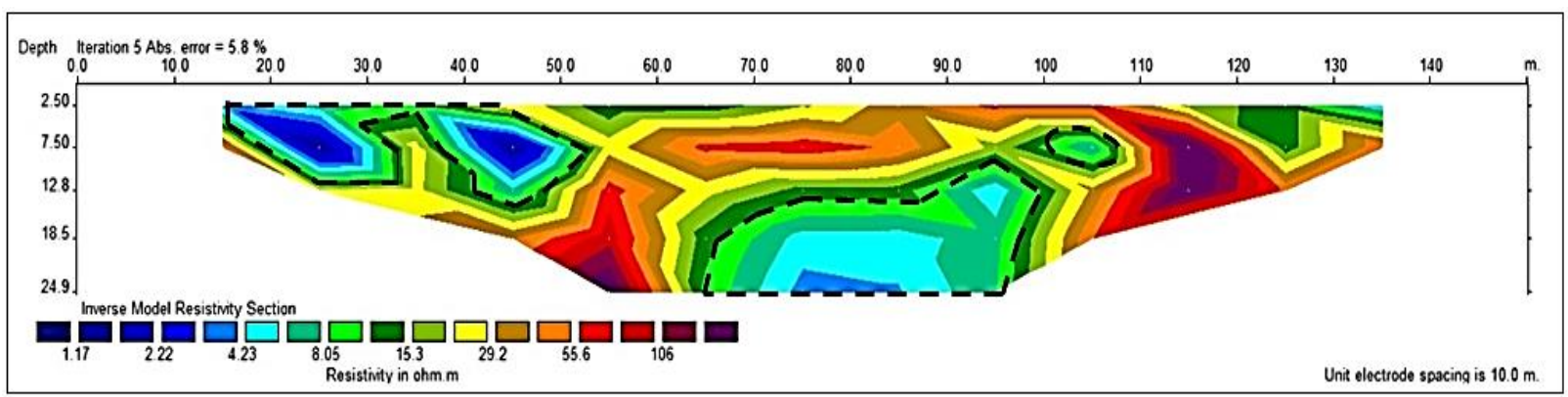

Figure 6. The 2-D cross-section contour of lower rock surface resistivity in trajectory 1.

Based on RES2DINV processing data, it can be seen that the distribution of iron sand deposits in trajectory 1 is spread along the research track forming sediment spots. The processing data in the form of format (.xyz) is reprocessed using ROCKWORK software to find out the volume (Figure 7), it appears that the distribution of iron sand deposits processed by ROCKWORK has synchronized with the results shown by RES2DINV processing results. Based on the calculation of the volume with a resistivity value limit between $0-10 \Omega \mathrm{m}$ the volume of iron sand trajectory 1 is $109,355 \mathrm{~m}^{3}$. 


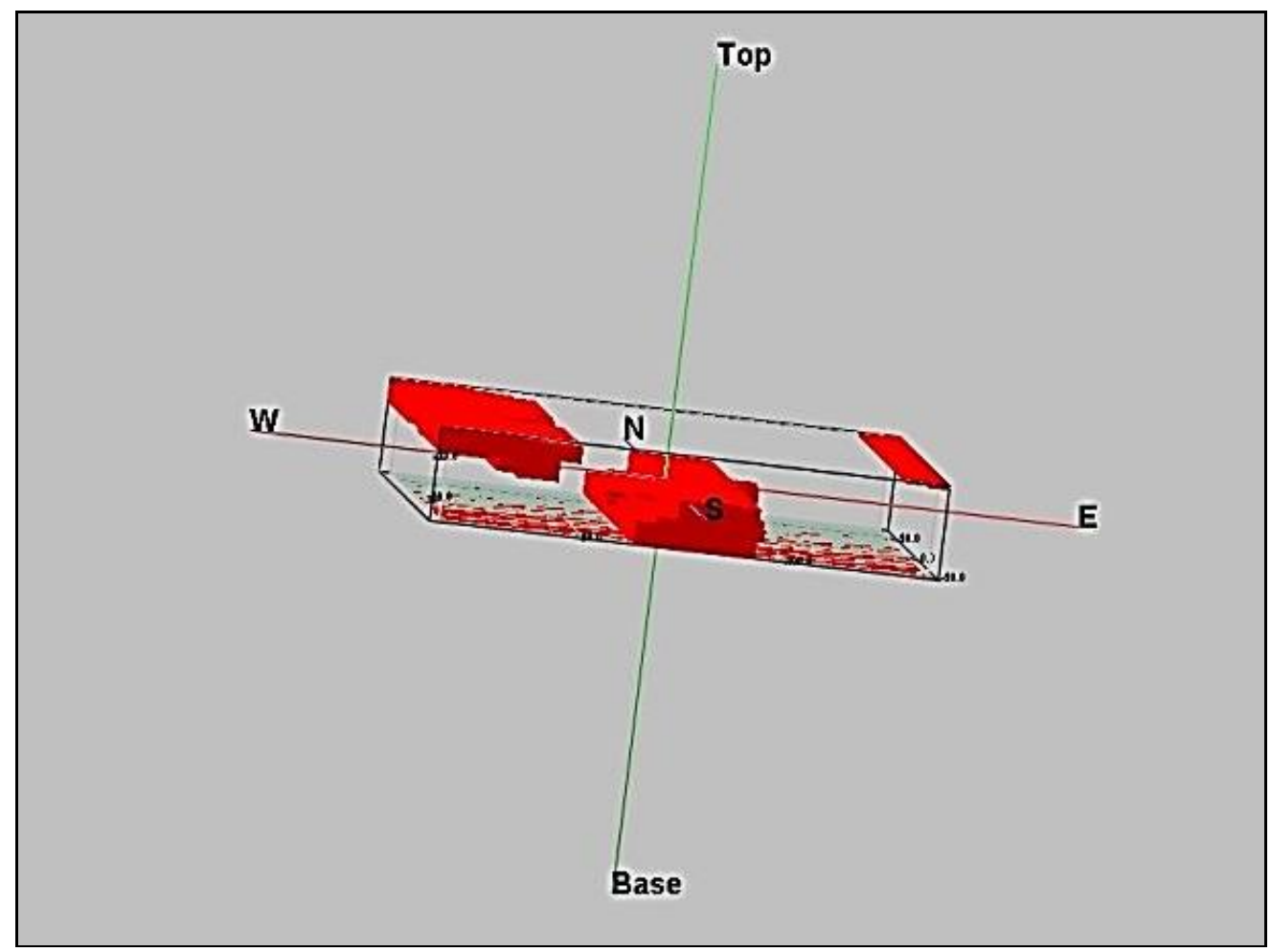

Figure 7. The Pseudo 3-D cross-sectional area of iron sand in trajectory 1.

Trajectory 2: based on the inversion results of the 2-D cross-sectional resistivity data (Figure 8), visible resistivity contrast with dark blue to light blue is interpreted as a layer of iron sand deposition $(\rho<10 \Omega \mathrm{m})$ on trajectory 2 the distribution of iron sand deposits is not seen as spots, but spread evenly along the second track starting from a distance of 15-130 m, at a depth of 2.5-15 meters below the surface. Variation of resistivity contrast of the second trajectory indicated the clay rock at a depth of 12-18 m below the surface, with a green color (30 $\mu \mathrm{m} \quad<\rho<80 \mu \mathrm{m})$. Also, breccia rocks spreading along the trajectory, shown based on resistivity contrast with yellow, red to purple $(\rho>100 \Omega \mathrm{m})$.

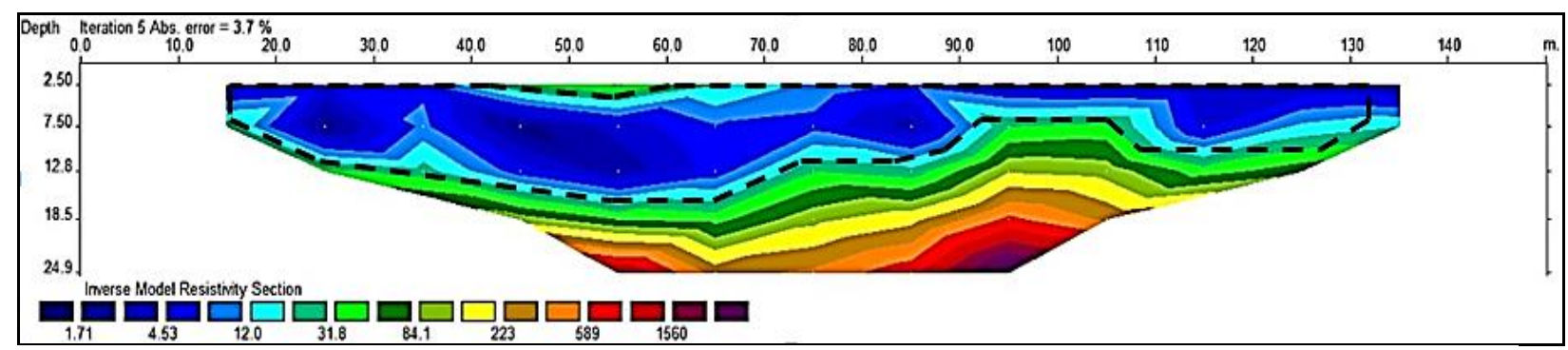

Figure 8. The 2-D Cross-section contour of rock bottom resistivity of trajectory surface 2.

The resistivity data of pseudo-crosssection 3-D based on RES2DINV (Figure 9) shows the existence of the same spread pattern between 2-D cross-section inversion results and 3-D Cross-section, where the deposition of iron sand is spread evenly along the general track on the surface and not forming spots. The volume of iron sand deposits has a greater amount of about $180,254 \mathrm{~m}^{3}$. 


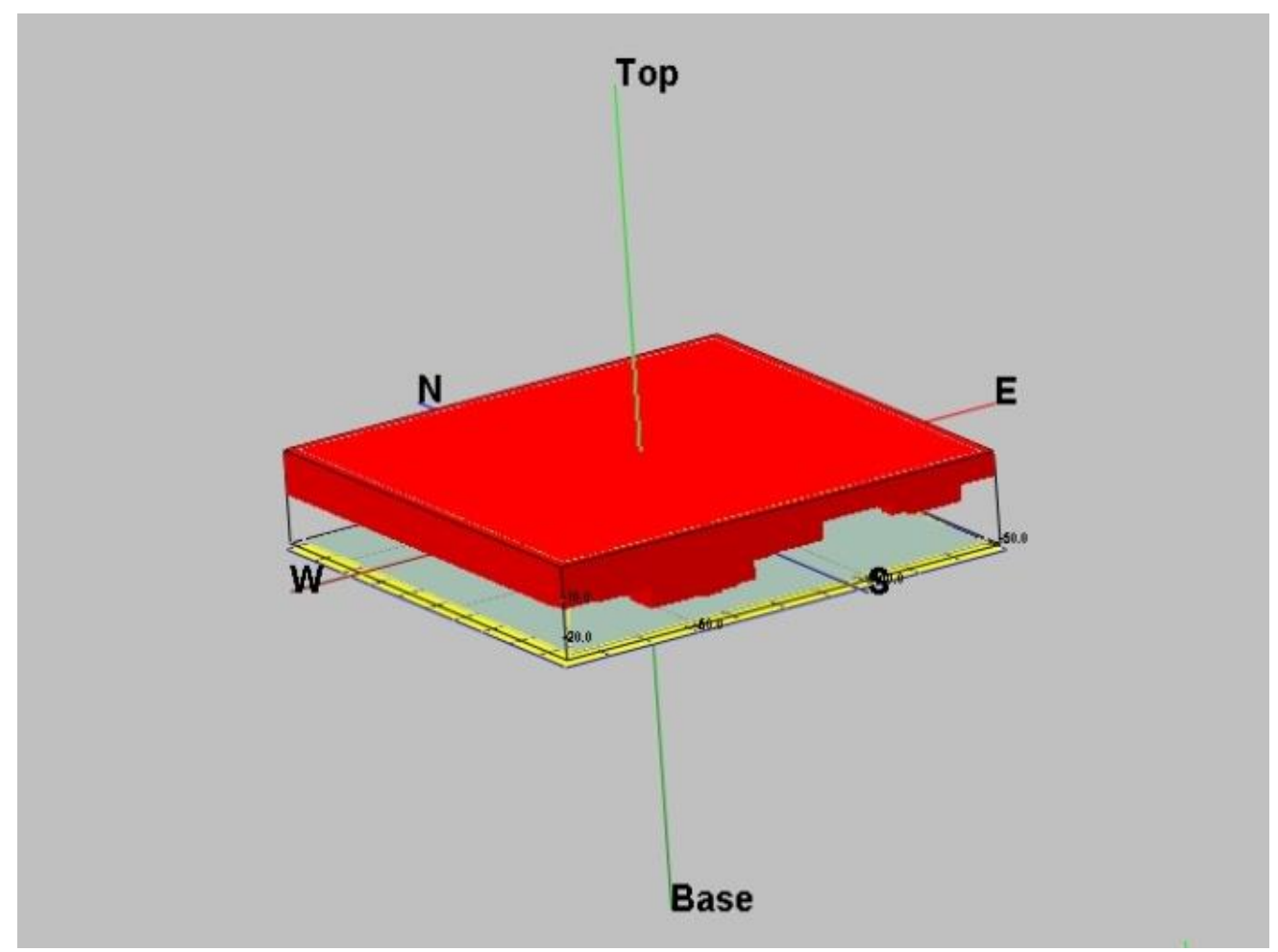

Figure 9. Cross-section of pseudo 3-D trajectory 2.

Trajectory 3: processing the 2-D crosssection inversion (Figure 10) shows the presence of iron sand deposits spread along path 3 by forming spots at a depth of 2.5-15 $\mathrm{m}$ below the surface, based on contrasting resistivity values with blue to light blue image $(\rho<10 \Omega \mathrm{m})$. Cross-section 2-D inversion cross-section also shows the variation of resistivity contrast with a range of values between $20 \Omega \mathrm{m}-60 \Omega \mathrm{m}$ (dark green to an orange color), it interpreted as a clay rock layer that spread along the track at a depth of 2.5 - 25 meters below the surface. Line 3 also shows indications of breccia rocks forming spots at a depth of 25 meters below the surface with resistivity values between $70 \Omega \mathrm{m}-150 \Omega \mathrm{m}$ (red to a purple).

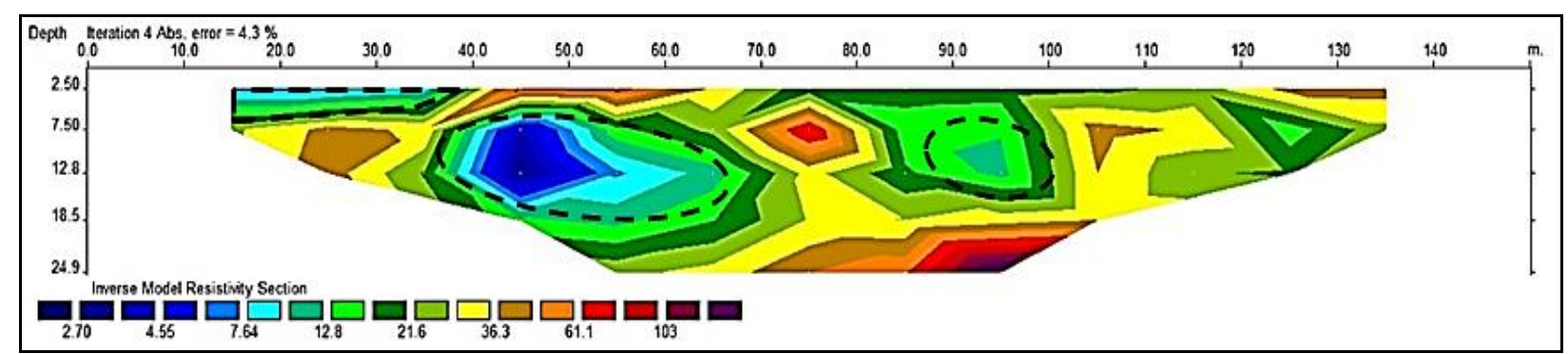

Figure 10. The Psudo 3-D cross-sectional area of iron sand in trajectory 3.

The 3-D cross-section of pseudo processing by ROCKWORK software (Figure 11), shows the correlation between 2-D and the pseudo-3-D resistivity data, where visible patterns of distribution of iron sand deposits form spots along the path. The number of iron sand deposits in the third lane is $120,556 \mathrm{~m}^{3}$. 


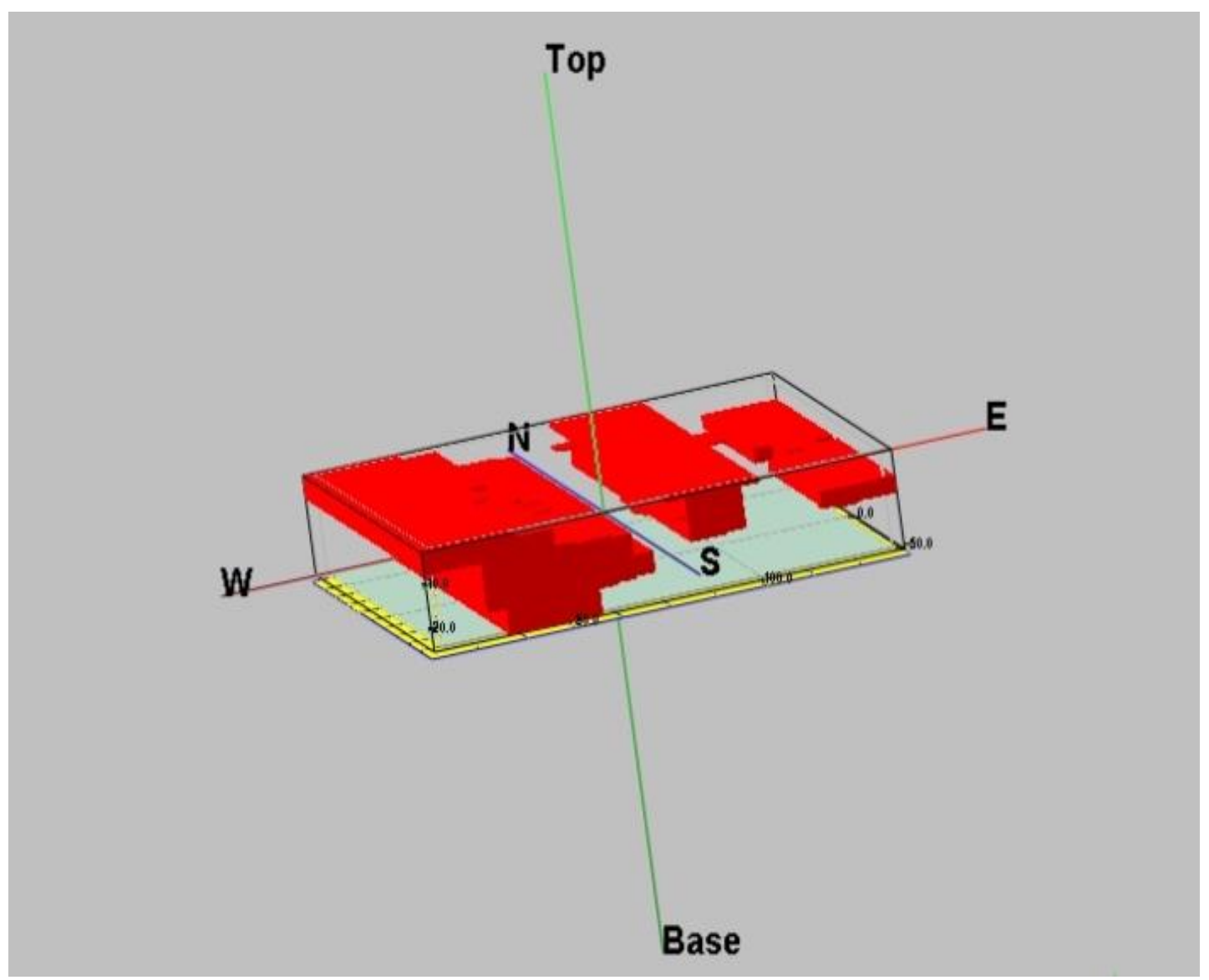

Figure 11. Cross-section of pseudo 3-D trajectory 3.

Combined 3-D Model: to obtain the overall volume of iron sand spread in the form of sediment along the coast of Wari Ino, it is necessary to combine resistivity contrast values in the form of inversion format (.xyz) into the 3-D form using ROCKWORK software (Figure 12). The results of the combination of these three tracks will produce a pseudo-3-D model. Therefore, we can easily see the pattern of distribution of iron sand deposits along the coast of Wari Ino. Based on the 3-D crosssection model, a low resistivity value contrast with a range of $\rho<10 \Omega \mathrm{m}$ values is interpreted as an iron sand precipitate, besides, it also shows a high resistivity contrast value $(10 \Omega \mathrm{m}<\rho<52 \Omega \mathrm{m})$. Thus clearly visible distribution patterns of iron sand deposits that trending from west to east of the study area. Figure 13 is a profile of a 3-D pseudo section that already has a limit value of $\rho<10 \Omega \mathrm{m}$ which is interpreted as the distribution of iron sand deposits with the total volume reaching $405,335 \mathrm{~m}^{3}$.

In short, the Wenner-Schlumberger configuration has been successfully applied to investigate the distribution and volume of the iron sand both for mapping and sounding methods. This method is powerful to obtain a 2D-model for the distribution and the 3D-model of the volume of the iron sand, as reported by (Jamaluddin \& Umar, 2018; Sehah et al., 2018; Sunarya et al., 2017). 


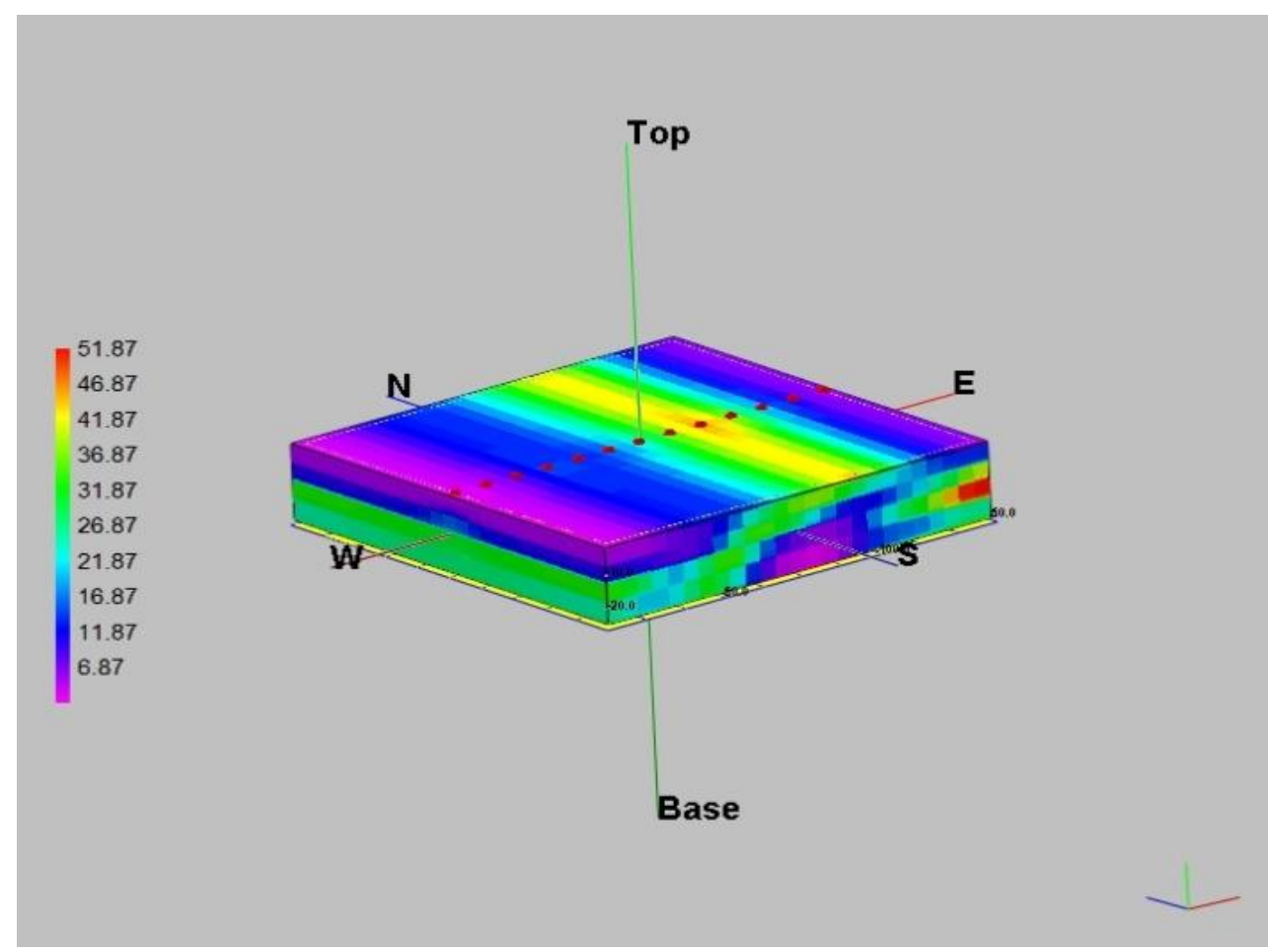

Figure 12. The 3-D pseudo section for trajectory 1-3.

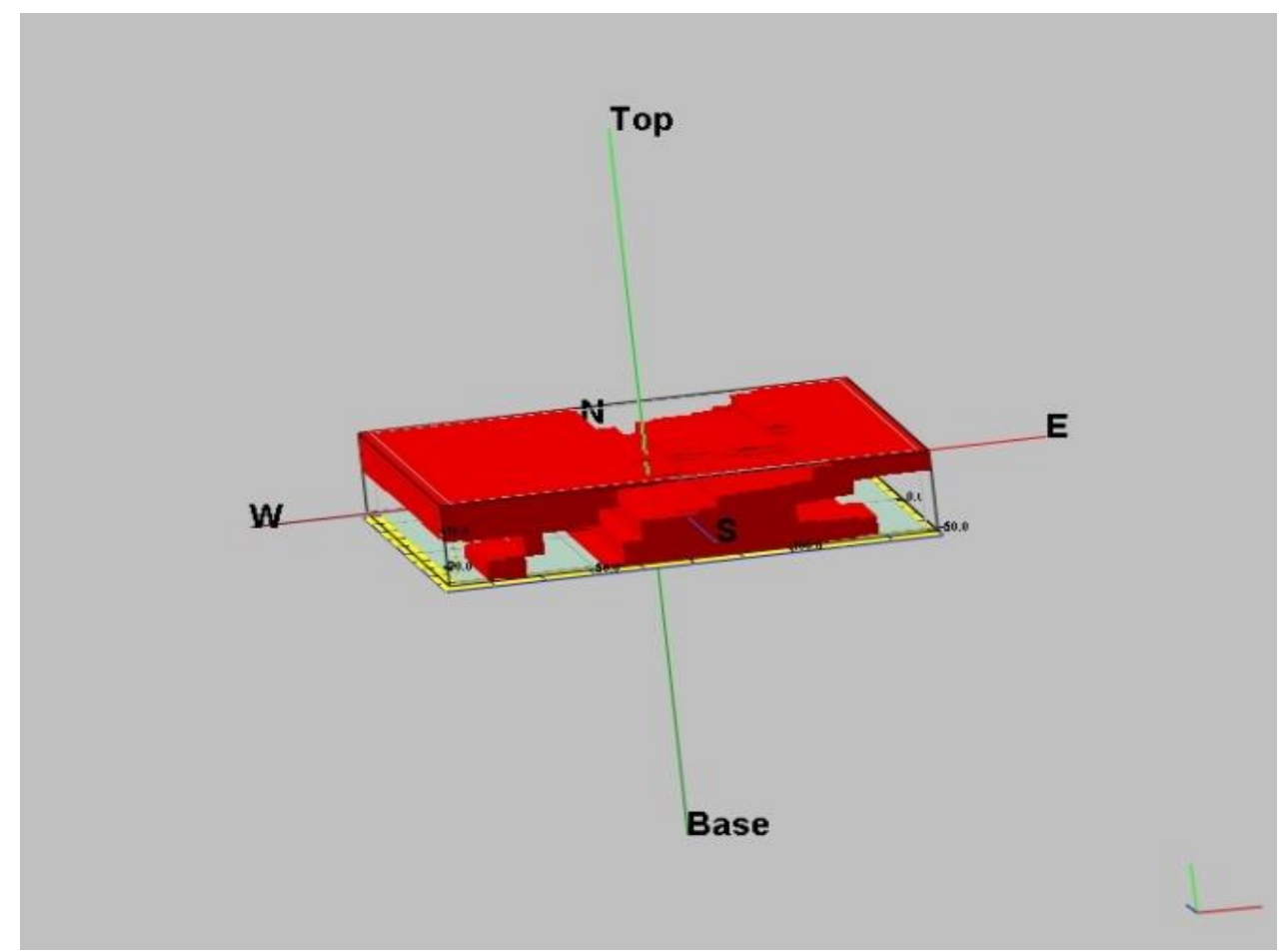

Figure 13. Distribution of iron sand deposits in pseudo-sedimentation 3-D.

\section{The Fe Content in Iron Sand Samples}

The elemental composition of raw iron sand samples for each trajectory can be presented in Figure 14. These results only a general profile of the $\mathrm{Fe}$ content in samples that are taken only in one location for every trajectory. In this research, the iron sand samples were collected only from the surface of the beach. The XRF spectra (Figure 15) confirm that the Fe composition 
in each sample is in the biggest volume. The composition of $\mathrm{Fe}$ in the form of $\mathrm{Fe}_{2} \mathrm{O}_{3}$ in the iron sand sample of trajectory 1 is about $57.92 \%$. Sample in trajectory 2 consisted of about $45.82 \% \quad \mathrm{Fe}_{2} \mathrm{O}_{3}$ and $65.47 \%$ in the sample of trajectory 3 . The elemental characterization also gives information about the composition of $\mathrm{Fe}$ in the form of free Fe element. Sand sample in trajectory 1 consisted of $67.41 \% \mathrm{Fe}$ element, while samples in trajectory 2 and 3 consisted of
$57.12 \%$ and $73.40 \%$. Roughly, those results are contrasted to the results provided by the resistivity method due to different $\mathrm{Fe}$ content versus volume for each trajectory. The resistivity method interprets the volume of iron sand until certain deep. For providing a general conclusion about the $\mathrm{Fe}$ content in the entire iron sand samples, further, we need more iron sand samples along the trajectories.
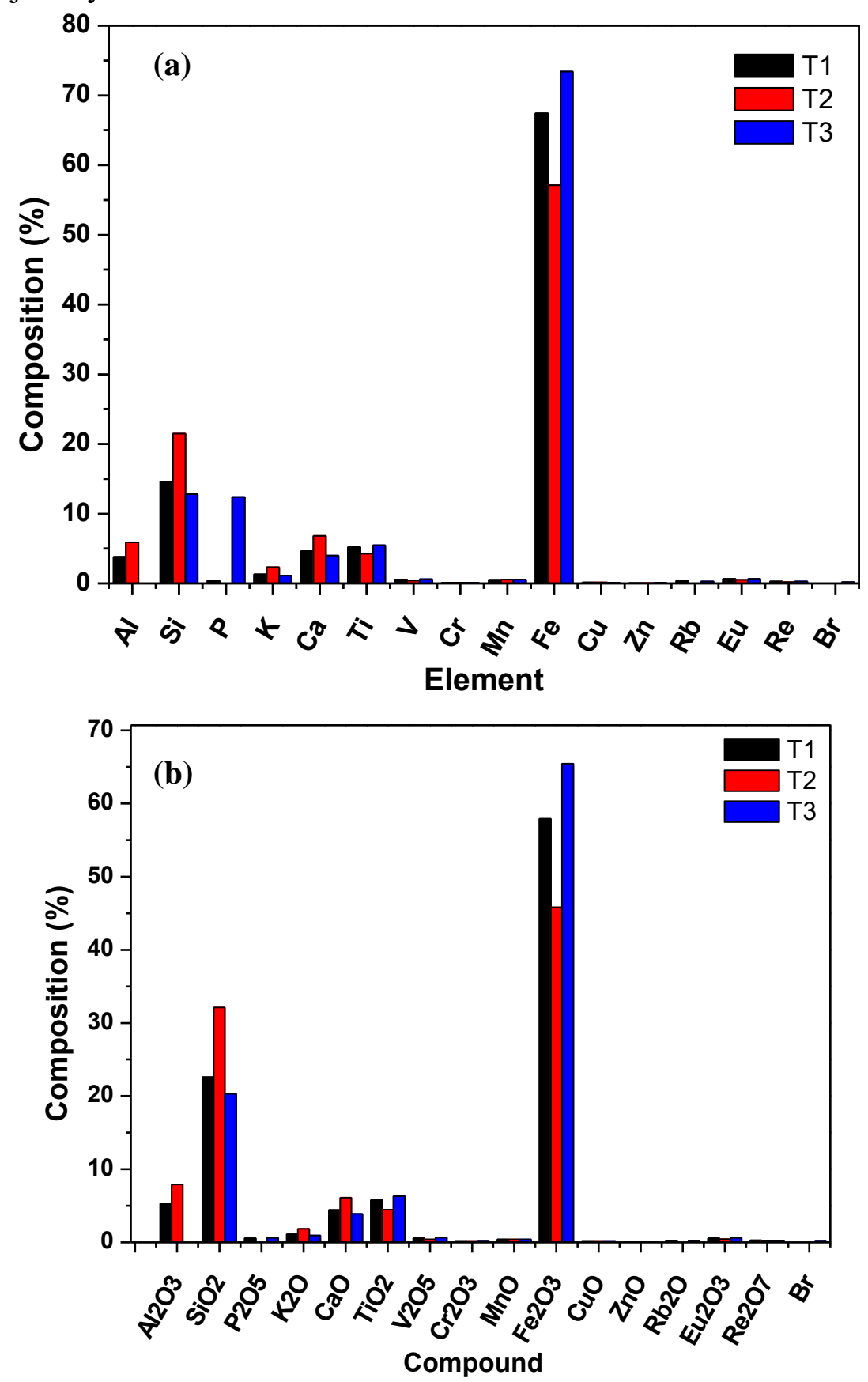

Figure 14. Fe content in iron sand samples of trajectory 1 (T1), trajectory 2 (T2), and trajectory 3 (T3): (a) Fe free element and (b) Fe compound in the form of $\mathrm{Fe}_{2} \mathrm{O}_{3}$. 

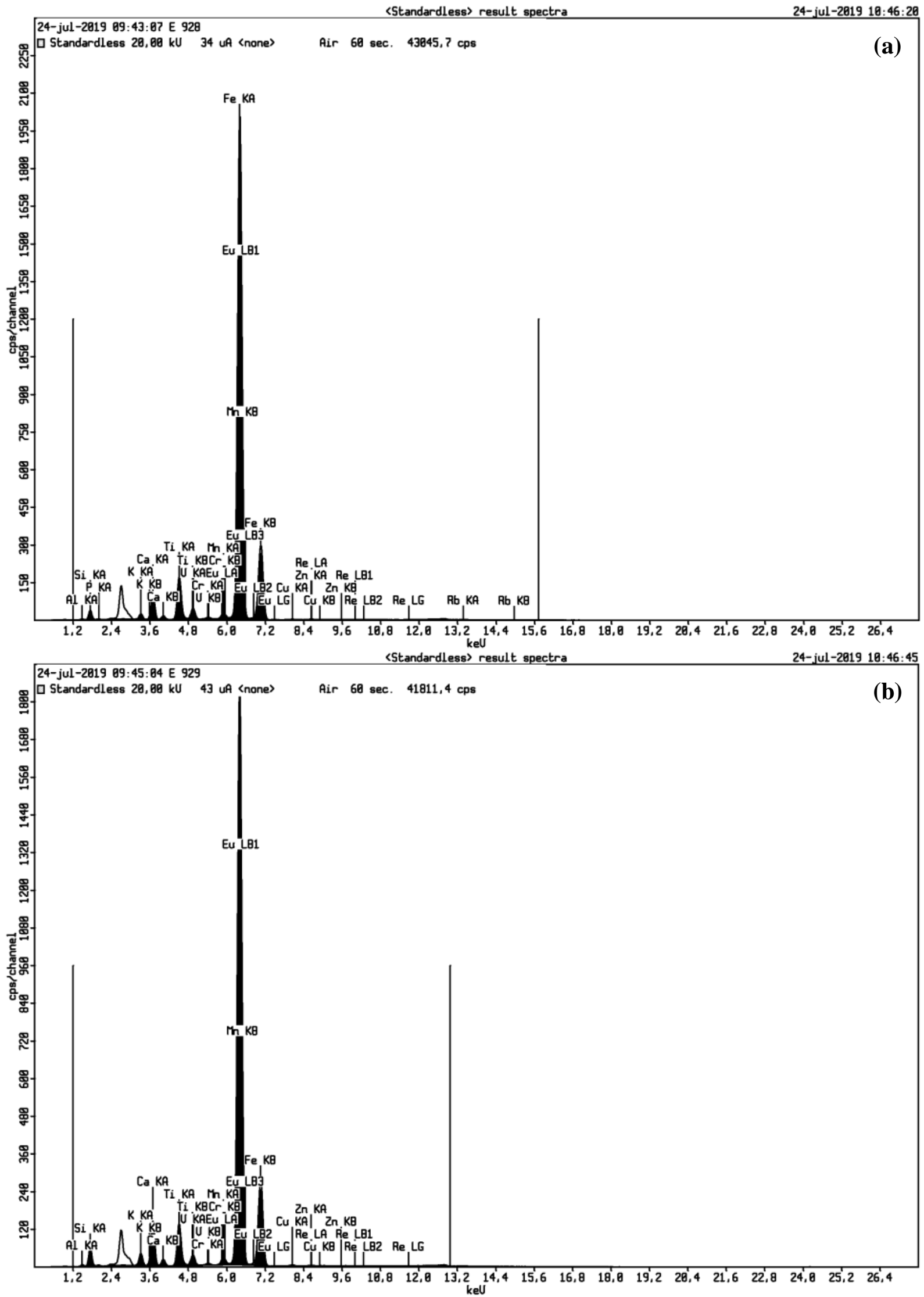


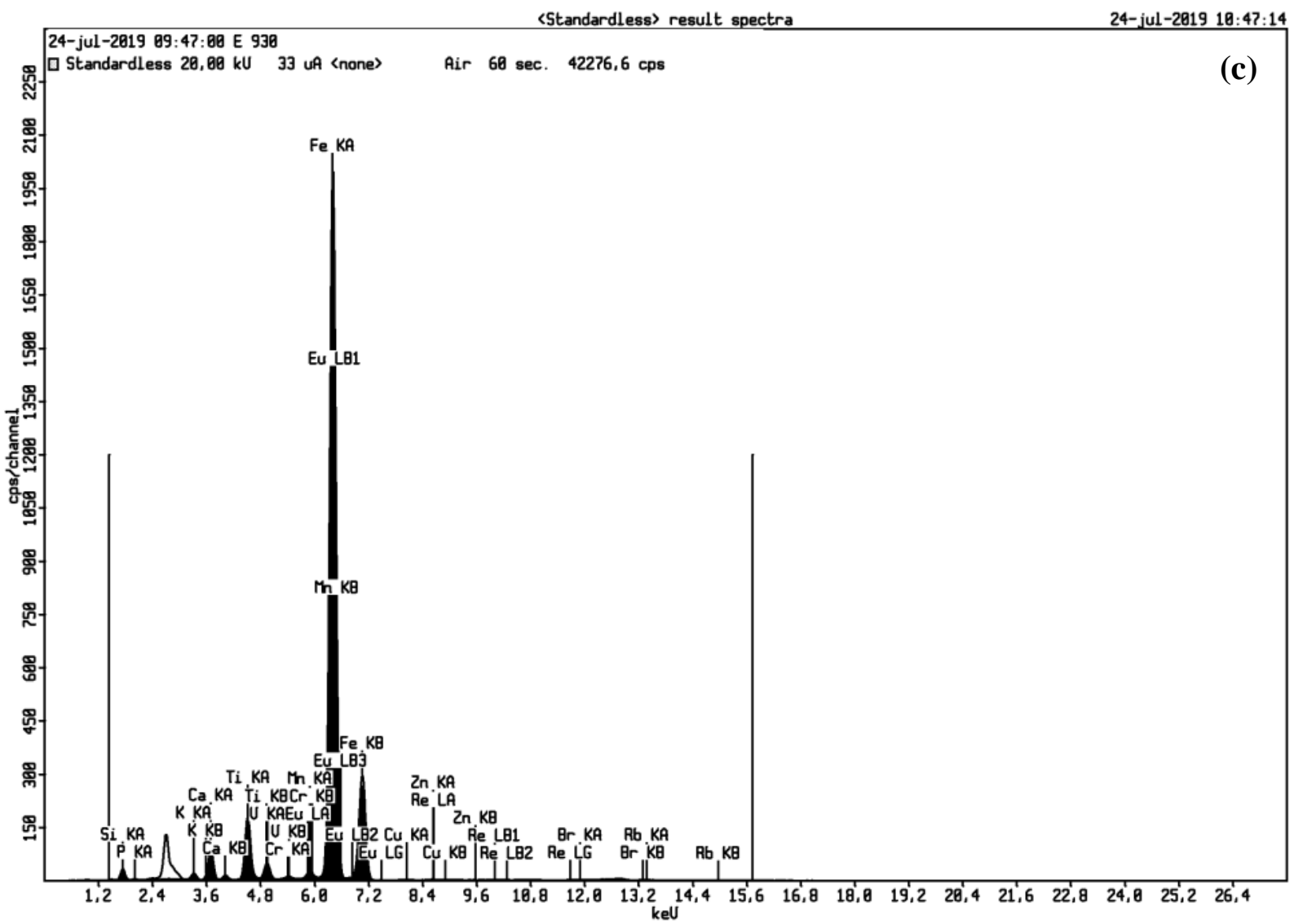

Figure 15. The XRF spectra of iron sand samples in: (a) trajectory 1 (T1), (b) trajectory 2 (T2), and (c) trajectory 3 (T3).

According to Figure 14 and Figure 15, other elements and their compounds have been also identified in iron sand samples. Silica ( $\mathrm{Si}$ ) in the form of free element and compound of $\mathrm{SiO}_{2}$ has a large composition after Fe. Other elements such as $\mathrm{Al}, \mathrm{P}, \mathrm{Ca}$, $\mathrm{K}, \mathrm{Ti}, \mathrm{V}, \mathrm{Cr}, \mathrm{Mn}, \mathrm{Cu}, \mathrm{Zn}, \mathrm{Rb}, \mathrm{Eu}, \mathrm{Rb}$, and $\mathrm{Br}$ have smaller composition than $6.0 \%$. These results are in agreement with the previous research reported by (Malega et al., 2018).

\section{CONCLUSION}

The investigation of the distribution and concentration of iron sand at Wari Ino Beach Tobelo has carried out by using the resistivity method with the WernerSchlumberger configuration. The total volume of iron sand deposit distributed along $450 \mathrm{~m}$ of the Wari Ino beach line and under $25 \mathrm{~m}$ in deep is $405,335 \mathrm{~m}^{3}$. The iron sand volume for each trajectory is 109,355 $\mathrm{m}^{3} ; \quad 180,254 \mathrm{~m}^{3} ;$ and $120,556 \mathrm{~m}^{3}$,

consecutively for trajectory 1,2 , and 3 . The $\mathrm{Fe}$ content in the form of a free element is $67.41 \%, 57.12 \%$, and $73.40 \%$. Furthermore, the $\mathrm{Fe}$ content in the form of $\mathrm{Fe}_{2} \mathrm{O}_{3}$ for the consecutive trajectories is $57.92 \%, 45.82 \%$, and $65.47 \%$. These novel results confirm that a potential exploration of the iron sand might be done and a database has been obtained for local government, especially the Department of Mining and Energy Service, Maluku Utara for further iron sand industry strategic plan in Halmahera Utara.

\section{ACKNOWLEDGMENTS}

Authors would like thank to the Government of Indonesia especially to the Ministry of Research and the Higher Education Republic of Indonesia toward PDP Research Scheme contract no. 118/SP2H/LT/DRPM/ 2019. Further, the author also thanks Universitas Halmahera toward LPPMP and Agency of the Environment North Halmahera for the facilities during the research. 


\section{AUTHOR CONTRIBUTIONS}

BA, IP and SI collected and analysed data. IP and SI display data. RU design schema of the research procedure and prepared literature relevant to research. BA conceptualized and prepared research method.

\section{REFERENCES}

Adewuyi, S. O., \& Ahmed, H. A. M. (2019). Geophysical techniques and their applications in mining. International Journal of Engineering Sciences \& Research Technology, 8(1). https://doi.org/10.5281/zenodo.254988 9

Adlim, M., Khaldun, I., Rahmi, M., Hasanah, U., Karina, S., \& Zulkiram, Z. (2019). Determination of iron content within iron sands from lampanah-lengah estuary using various analytical methods. Journal of Physics: Conference Series, 1-8. https://doi.org/10.1088/17551315/348/1/012007

Akmam, Amir, H., Putra, A., Anshari, R., \& Jalinus, N. (2019). Implementation of least-square constrain inversion method of geoelectrical resistivity data wennerschlumberger for investigation the characteristic of landslide. Journal of Physics: Conference Series, 1-11. https://doi.org/10.1088/17426596/1185/1/012013

Arista, D., Rachmawati, A., Ramadhani, N., Saputro, R. E., Taufiq, A., \& Sunaryono. (2019). Antibacterial performance of Fe3O4/PEG-4000 prepared by co-precipitation route. Journal of Physics: Conference Series, 1-9. $\quad$ https://doi.org/10.1088/1757899X/515/1/012085

Arsyad, M., Tiwow, V. A., \& Rampe, M. J. (2018). Analysis of magnetic minerals of iron sand deposit in sampulungan beach, takalar regency, south sulawesi using the x-ray diffraction method. Journal of Physics: Conference Series, 1-9. $\quad$ https://doi.org/10.1088/1742-
6596/1120/1/012059

Azmiyawati, C., Suyati, L., Taslimah, \& Anggraeni, R. D. (2017). Coating of Sulfonic Silica onto Magnetite from Coating of Sulfonic Silica onto Magnetite from Marina Beach Iron sand, Semarang , Indonesia. Journal of Physics: Conference Series, 1-8. https://doi.org/10.1088/17426596/755/1/011001

Bolívar, W. M., \& González, E. E. (2019). Glutathione $\mathrm{Fe} 3 \mathrm{O} 4$ nanoparticles as efficient material for the adsorption of mercury(II) from water at low concentrations. Global Journal of Science Frontirer Research: B, 9(1), 115.

Chandra, J., \& Hall, R. (2016). Tectonostratigrafic evolution and hydrocarbon prospectivity of the South Halmahera Basin, Indonesia. Proceedings of the Indonesian Petroleum Association 27th Annual Convention, 1-7.

Dahlan, K., Haryati, E., \& Aninam, Y. S. (2018). Potential of iron sand from betaf beach, sarmi regency and river sand from Doyo, Jayapura Regency, Papua as basic materials of mortar as nuclear radiation shielding. Journal of Physics: Conference Series, 1-7. https://doi.org/10.1088/17426596/997/1/012023

Dang, B., Chen, Y., Wang, H., Chen, B., Jin, C., \& Sun, Q. (2018). Preparation of high mechanical performance Nano$\mathrm{Fe} 3 \mathrm{O} 4 / \mathrm{Wood}$ fiber binderless composite boards for electromagnetic absorption via a facile and green method. Nanomaterials, 8(52), 1-17. https://doi.org/10.3390/nano-8010052

Fahlepy, M. R., Tiwow, V. A., \& Subaer. (2018). Characterization of magnetite (Fe3O4) minerals from natural iron sand of Bonto Kanang village Takalar for ink powder (toner) Application. Journal of Physics: Conference Series. https://doi.org/10.1088/17426596/997/1/012036

Fahmiati, Nuryono, \& Suyanta. (2017). 
Characteristics of iron sand magnetic material characteristics of iron sand magnetic material from bugel beach, Kulon Progo, Yogyakarta. Journal of Physics, $1-9$. https://doi.org/10.1088/17426596/755/1/011001

Haryati, E., \& Dahlan, K. (2018). Potential of iron sand from betaf beach, sarmi regency and river sand from Doyo, Jayapura Regency, Papua as Basic Materials of mortar as nuclear radiation shielding. Journal of Physics: Conference $\quad$ Series, 1-6. https://doi.org/10.1088/17426596/997/1/012043

Imran, M., Ansari, A. R., Shaik, A. H., Abdulaziz, Hussain, S., Khan, A., \& Chandan, M. R. (2018). Ferrofluid synthesis using oleic acid coated $\mathrm{Fe} 3 \mathrm{O} 4$ nanoparticles dispersed in mineral oil for heat transfer applications. Material Research Express, 5(036108), 1-8. https://doi.org/10.1088/20531591/aab4d7

Jamaluddin, \& Umar, E. P. (2018). Identification of subsurface layer with wenner- schlumberger arrays configuration geoelectrical method. Journal of Physics: Conference Series, 1-7. $\quad$ https://doi.org/10.1088/17551315/118/1/012006

Lawan, A., Raimi, J., \& Ahmed, A. (2018). Characterization of the Iron ore deposit using 2D resistivity imaging and induced polarization technique at diddaye-potiskum area, Northeastern Nigeria. Physical Science \& Biophysics Journal, 2(1), 1-12.

Malega, F., Indrayana, I. P. ., \& Suharyadi, E. (2018). Synthesis and characterization of the microstructure and functional group bond of fe 304 nanoparticles from natural iron sand in Tobelo North Halmahera. Jurnal Ilmiah Pendidikan Fisika Al-Biruni, 7(2), 13-22. https://doi.org/10.24042/ jipfalbiruni.v7i2.2913
Maulinda, Zein, I., \& Jalil, Z. (2019). Identification of magnetite material (Fe3O4) based on natural materials as catalyst for industrial raw material application. Journal of Phys, 1-7. https://doi.org/10.1088/17426596/1232/1/012054

Naveen, K. T., Rama, R. P., \& Naganjaneyulu, K. (2015). Electrical resistivity imaging (ERI) using multielectrodes for studying subsurface formations in Cauvery plains. Advances in Applied Science Research, 6(5), 47-53.

Nurrohman, D. T., \& Pribadi, J. S. (2018). Kajian struktur kristal, lattice strain, dan komposisi kimia nanopartikel pasir besi yang disintesis dengan metode ball milling. Konstan: Jurnal Fisika Dan Pendidikan Fisika, 3(2), 47-54.

Octova, A., \& Yulhendra, D. (2017). Iron Ore deposits model using geoelectrical resistivity method with dipole-dipole array. MATEC Web of Conferences, 101(04017). https://doi.org/10.1051/ matecconf/201710104017

Pratiwi, E. S., Sartohadi, J., \& Wahyudi. (2019). Geoelectrical prediction for sliding plane layers of rotational landslide at the volcanic transitional landscapes in Inonesia. IOP Conference Series: Earth and Enviromental Science.

Pratiwi, Y., Ramli, \& Ratnawulan. (2017). Pengaruh waktu milling terhadap struktur kristal magnetite (Fe3O4) berbahan dasar mineral vulkanik dari gunung talang sumatera barat. Pillar of Physics, 10, 102-108.

Raharjo, S. A., \& Sehah. (2018). Eksplorasi Potensi Pasir Besi di Pesisir Barat Kecamatan Nusawungu Kabupaten Cilacap Berdasarkan Data Resistivitas Batuan Bawah Permukaan. Jurnal Fisika Dan Aplikasinya, 14(3), 51-58.

Rahimnia, R., Salehi, Z., Ardestani, M. S., \& Doosthoseini, H. (2019). SPION conjugated curcumin nano-imaging probe: Synthesis and bio-physical 
evaluation. Iranian Journal of Pharmaceutical Research, 18(1), 183197.

Rahmawati, R., Melati, A., Taufiq, A., Sunaryono, Diantoro, M., Yuliarto, B., Suyatman, S., Nugraha, N., \& Kurniadi, D. (2017). Preparation of MWCNT-Fe3O4 nanocomposites from iron sand using sonochemical route. Journal of Physics: Conference Series, 2-8. $\quad$ https://doi.org/10.1088/1757899X/202/1/012013

Ramelan, A. H., Wahyuningsih, S., Ismoyo, Y. A., Pranata, H. P., \& Munawaroh, H. (2016). Preparation of xerogel $\mathrm{SiO}_{2}$ from roasted iron sand under various acidic solution. Journal of Physics: Conference $\quad$ Series, 1-7. https://doi.org/10.1088/17426596/776/1/012032

Rettob, A. L. (2019). Coating of iron sand magnetic material with aminobenzimidazole modified silica via green process. Journal of Physics: Conference Series, 1-8. https://doi.org/10.1088/17551315/235/1/012075

Rianto, D., Yulfriska, N., Murti, F., Hidayati, H., \& Ramli, R. (2018). Analysis of crystal structure of $\mathrm{Fe} 3 \mathrm{O} 4$ thin films based on iron sand growth by spin coating method. Journal of $P, 1-8$. https://doi.org/10.1088/1757$899 X / 335 / 1 / 012012$

Sardana, N., Singh, K., Saharan, M., Bhatnagar, D., \& Ronin, R. S. (2018). Synthesis and characterization of dendrimer modified magnetite nanoparticles and their antimicrobial activity for toxicity analysis. Journal of Integrated Science and Technology, 6(1), 1-5.

Satriani, A., Loperte, A., Imbrenda, V., \& Lapenna, V. (2012). Geoelectrical surveys for characterization of the coastal saltwater intrusion in metapontum forest reserve (Southern Italy). International Journal of Geophysics, 2012(238478), 1-8. https://doi.org/10.1155/2012/238478

Sebayang, P., Kurniawan, C., Aryanto, D., Setiadi, E. A., Tamba, K., Djuhana, \& Sudiro, T. (2018). Preparation of $\mathrm{Fe} 3 \mathrm{O} 4 /$ bentonite nanocomposite from natural iron sand by co-precipitation method for adsorbents materials. Journal of Physics: Conference Series, 1-8. $\quad$ https://doi.org/10.1088/1757899X/316/1/012053

Sehah, Raharjo, S. A., \& Aziz, A. N. (2018). Coastal hydrogeological model in the iron ore prospect area of widarapayung coastal, cilacap regency based on 2Dresistivity data. Jurnal Penelitian Fisika Dan Aplikasinya, 8(2), 71-83. https://doi.org/10.26740/ jpfa.v8n2.p71-83

Sehah, Raharjo, S. A., \& Destiani, F. (2018). Interpretation of 2D-subsurface resistivity data in the iron ore prospect area of eastern binangun coastal, regency of cilacap, Central Jawa. Journal of Geoscience, Engineering, Environment, and Technology, 3(4), 213-220. https://doi.org/10.24273/jgeet.2018.3.4. 2139

Setiadi, E. A., Sebayang, P., Ginting, M., Sari, A. Y., Kurniawan, C., Saragih, C. S., \& Simamora, P. (2016). The synthesization of $\mathrm{Fe} 3 \mathrm{O} 4$ magnetic nanoparticles based on natural iron sand by co-precipitation method for the used of the adsorption of $\mathrm{Cu}$ and $\mathrm{Pb}$ Ions. Journal of Physics: Conference Series, 776(012020). https://doi.org/10.1088/ 17426596/776/1/012020

Sunarya, W., Hasanuddin, Syamsudin, Maria, \& Erfan. (2017). Identifikasi bijih besi (fe) menggunakan metoda geolistrik resistivitas konfigurasi werner-schlumberger di kabupaten luwu. Jurnal Geocelebes, 1(2), 72-81.

Suprapto, S. J., \& Sunuhadi, D. N. (Eds.). (2014). Pasir besi di indonesia: geologi, eksplorasi dan pemanfaatannya. Pusat Sumber Daya 
Geologi, Ministry of Energy and Mineral Resources.

Taufiq, A., Saputro, R. E., Sunaryono, Hidayat, N., Hidayat, A., Mufti, N., Diantoro, M., Patriati, A., Mujamilah, Putra, E. G. R., \& Nur, H. (2017). Fabrication of magnetite nanoparticles dispersed in olive oil and their structural and magnetic investigations. IOP Conference Series: Materials Science and Engineering, 202(012008). https://doi.org/10.1088/1757899X/202/ $1 / 012008$

The Indonesia Iron and Steel Industry Asscociation. (2017). Indonesia steel industry: Development \& opportunities.

Putri, W., B., K., Setiadi, E. A., Herika, V., Tetuko, A. P., \& Sebayang, P. (2019). Natural iron sand-based $\mathrm{Mg}$ 1-X $\mathrm{NixFe} 2 \mathrm{O} 4$ nanoparticles as potential adsorbents for heavy metal removal synthesized by co-precipitation method. Journal of Physics: Conference $\quad$ Series, 1-6. https://doi.org/10.1088/1755-
$1315 / 277 / 1 / 012031$

Yulfriska, N., Rianto, D., Murti, F., Darvina, Y., \& Ramli, R. (2018). Optical properties of $\mathrm{Fe} 3 \mathrm{O} 4$ thin films prepared from the iron sand by spin coating method. Journal of Physics: Conference Series, 1-8. https://doi.org/10.1088/1757899X/335/1/012010

Yulianto, A., Fitriawan, M., \& Sumpono, I. (2019). Synthesis of iron sand into yellow nano-pigment using sol-gel method. Journal of Physics: Conference Series, 1-6. https://doi.org/10.1088/17426596/1170/1/012049

Yusmaniar, Y., A, W. A., Hutomo, D. K., \& Handoko, E. (2018). Electromagnetic wave absorbing properties of husk silica-based $\quad \mathrm{SiO} 2 / \mathrm{Fe} 3 \mathrm{O} 4 / \mathrm{UPR}$ composite. Journal of Physics: Conference Series, 1-8. https://doi.org/10.1088/1757899X/434/1/012081 